\title{
NEWS TEXT: GENRE TRANSFORMATION
}

\author{
Yana A. Volkova \\ Peoples' Friendship University of Russia, Moscow, Russia \\ Nadezhda N. Panchenko \\ Volgograd State Socio-Pedagogical University, Volgograd, Russia
}

\begin{abstract}
The article considers a news text as a secondary type of text where news content undergoes modifications as a result of humorous interpretation. New trends in media coverage, which lead to a change in its format and linguistic content, are analyzed. The creation of a secondary news text / genre is shown as performed through transforming the main (primary) news text. The secondary media text belongs to the comic picture of the world, the modeling of which becomes possible due to various means of the comic which fulfill social-critical, aesthetic and entertainment functions. The empirical material of the study comprises 530 news texts telecast at the beginning of the program "Evening Urgant" on Channel One in 2017-2020. The identified mechanism of news transformation includes the use of irony, sarcasm, comic exaggeration and understatement, references to precedent phenomena, the techniques of allegory, comic dissonance and comic surprise, comic exposure, etc. The analysis of the news transformation mechanism revealed a reduction in the primary news component with a simultaneous "build-up" of a pragmatic component through the use of various means and techniques of the comic. This leads to the construction of a secondary news text, which, in turn, is characterized by a recombined semantic content and subjective interpretation of the primary news piece.
\end{abstract}

Key words: media text, news text, secondary text, transformation mechanism, comic.

Citation. Volkova Ya.A., Panchenko N.N. News Text: Genre Transformation. Vestnik Volgogradskogo gosudarstvennogo universiteta. Seriya 2. Yazykoznanie [Science Journal of Volgograd State University. Linguistics], 2021, vol. 20, no. 2, pp. 121-132. (in Russian). DOI: https://doi.org/10.15688/jvolsu2.2021.2.11

УДК 81 ' $42: 070$

ББК 81.055 .51 .5
Дата поступления статьи: 26.11.2020 Дата принятия статьи: 12.01.2021

\section{НОВОСТНОЙ ТЕКСТ: ЖАНРОВОЕ ПЕРЕВОПЛОЩЕНИЕ}

\author{
Яна Александровна Волкова \\ Российский университет дружбы народов, г. Москва, Россия
}

Надежда Николаевна Панченко

Волгоградский государственный социально-педагогический университет, г. Волгоград, Россия

Аннотация. В статье рассматривается новостной текст как вторичный тип текста, новостной контент в котором претерпевает модификации в результате юмористической интерпретации. Анализируются новые тенденции освещения медиановости, приводящие к изменению ее формата и языкового наполнения. Установлено, что создание вторичного новостного текста / жанра осуществляется путем трансформации основного (первичного) новостного текста. Показано, что особенность вторичного медиатекста состоит в его принадлежности к комической картине мира, моделирование которой становится возможным благодаря различным средствам комического, реализующим социально-критические, эстетические и развлекательные функции. Эмпирическим материалом исследования послужили 530 текстов новостной рубрики, транслируемой в начале передачи Первого канала «Вечерний Ургант» (2017-2020 гг.). Выявленный механизм новостной трансформации включает использование иронии, сарказма, комического преувеличения и преуменьшения, 
приемов иносказания, комического несоответствия и комической неожиданности, разоблачения, отсылки к прецедентным феноменам. Новостная трансформация способствует редуцированию первичного новостного компонента при одновременном «наращивании» прагматического компонента через использование различных средств и приемов комического, что приводит к конструированию вторичного новостного текста, который характеризуется рекомбинированным смысловым содержанием и субъективной интерпретацией первичной новости.

Ключевые слова: медиатекст, новостной текст, вторичный текст, механизм трансформации, комическое.

Цитирование. Волкова Я. А., Панченко Н. Н. Новостной текст: жанровое перевоплощение // Вестник Волгоградского государственного университета. Серия 2, Языкознание. - 2021. - Т. 20, № 2. - С. 121-132. DOI: https://doi.org/10.15688/jvolsu2.2021.2.11

\section{Введение}

В последние годы особую привлекательность для лингвистического изучения приобрели медиатексты, их жанровое своеобразие и закономерности процесса порождения. Интерес этот легко объясним. С одной стороны, медийный дискурс, ориентированный на создание информационно-текстовой среды и трансляцию новостей для массовой аудитории, всегда был, есть и будет социально значимым для любой лингвокультуры. С другой стороны, в настоящее время благодаря интерактивным возможностям отражения объективной реальности, глобальности интернетпространства он приобретает особую актуальность, а многообразие типов текстов, продуцируемых современными средствами массовой коммуникации, и изменение форм презентации информации подогревают исследовательское любопытство и стремление ученых систематизировать разнообразные по структуре и объему медиажанры.

Последние, как известно, позволяют судить об уровне развития общества, его потребностях и ожиданиях; образование жанров массмедиа определяется информационными запросами и коммуникативными интересами аудитории. Выработка новых жанровых моделей и типов медиатекстов далеко не всегда обусловлена стремлением к наиболее адекватному и достоверному отражению фактов, а в большинстве случаев направлена на удовлетворение ожиданий, потребностей и эмоциональных запросов массового адресата медийного дискурса. К подобным потребностям и ожиданиям массмедийной аудитории относится получение «легкого» - досугового, развлекательного, в том числе юмористического, - контента.
Цель данной статьи - охарактеризовать новостные тексты как вторичные типы текстов, новостной контент в которых претерпевает определенные модификации в результате юмористической интерпретации.

\section{Материал и методы}

Исследование развивает положения одного из актуальных направлений лингвистики текстолингвистики, опирается на научные изыскания отечественных специалистов в области теории вторичного текста [Вербицкая, 2000; Ионова, 2006; Полубитченко, 2017; и др.] и теории комического [Бахтин, 1997; Истомина, 2015; Палкевич, 2003; Попченко, 2005; и др.].

Медиатексты в последнее время претерпевают существенные изменения. В медиаиндустрии, включающей телевизионное, радио- и интернет-пространство, очевидна тенденция к трансформации и гибридизации жанров медиапродуктов. Нельзя не согласиться с А.Г. Пастуховым, утверждающим, что «медиасфера становится инновационной площадкой и одновременно сферой влияния, в которой на фоне глобализационных процессов происходят изменения их типологических характеристик: взаимодействие и взаимовлияние, развитие новых типов и жанров медиа, использование развлекательных форм в журналистике, ориентация на специфическую аудиторию или субкультуру и т. п.» [Пастухов, 2012, с. 183]. Не ставя своей целью систематизацию разнообразных по структуре и объему медиатекстов (см. обзор существующих классификаций: [Распопова, 2012]), охарактеризуем современные тенденции, наблюдаемые в массмедиа в общем и наиболее отчетливо заметные в информационных медиапродуктах, включая новостные произведения, в частности. 
Прежде всего обратим внимание на то, что традиционные жанры общественно-политического вещания зачастую утрачивают признаки «качественности», приобретают признаки «желтизны» [Вартанова, Смирнов, 2009], а серьезные новостные, аналитические программы уступают место «легкому» (игровому / зрелищному / юмористическому) контенту, лишенному социальной значимости.

Причинами для подобного замещения и постепенного смещения акцента с информативности на «досуговость» и развлекательность становятся процессы, происходящие в обществе и общественном сознании и влекущие за собой: а) снижение популярности информационных программ; б) уменьшение доли официальных новостей и увеличение количества известий о социальной и культурной жизни; в) изменение всей информационной среды, склонность современного телевидения к фрагментарному отражению действительности, поверхностности освещения событий [Евдокимов, 2010; Пастухов, 2012]. Помимо этого, условием возникновения гибридных информационно-развлекательных медиапродуктов выступает коммерциализация и конкуренция СМИ за привлечение внимания аудитории.

Информирование как основная прагматическая задача новостного текста осуществляется при реализации трех взаимосвязанных категорий - точности (высокой степени релевантности отражения события), достоверности (подлинности события, подтвержденной заслуживающими доверия источниками) и аттрактивности (привлекательной формы подачи материала) (см. об этом: [Мельникова, 2014]). В соответствии с современными тенденциями прямое отражение реальности становится непривлекательным и невостребованным, в результате чего соотношение категорий точности, достоверности и аттрактивности утрачивает сбалансированность - на первый план выдвигается аттрактивность, повышающая интерес массовой аудитории к событию в ущерб точности и достоверности. В угоду аттрактивности меняются и способы информирования: внимание потребителей новостей концентрируется на увлекательных подробностях и будоражащих деталях, усиливающих драматизм восприятия.
Нельзя не принимать во внимание фактор медиановостной субъективности, обусловленной двумя основными причинами. Вопервых, осуществляется селекция новостного потока (игнорирование одних и фиксация / тиражирование других новостей): попадание в список «новостных» факторов, согласно А.Г. Пастухову, вызывает к жизни активизацию таких факторов, как конфликт / контроверза, агрессия, насилие, персонализация, эмоции, эротика / секс, негативизм и др. [Пастухов, 2016, с. 64]. Во-вторых, субъективность новостного контента порождается индивидуальным восприятием и личностным вкладом журналиста в обработку новости. Не лишено оснований утверждение, что «знание технологий (сбора фактов, их обработки, изложения и т. д.) представляет собой лишь инструментальную схему воплощения творческого потенциала создателя медиатекста» [Ерофеева, 2014, с. 87]. Уместно в этой связи вспомнить журналистское клише «делаю новость».

Перечисленные факторы, объясняющие происходящие сегодня в новостном тексте изменения, имеют в большинстве случаев непреднамеренный, социально обусловленный характер.

Иначе обстоит дело с намеренной стратегией представления новостей, связанной с «перенастройкой» формата и ориентацией на определенную целевую аудиторию, с сознательным привнесением коннотаций, трансформирующих исходный новостной контент и подвергающих его различным преобразованиям и интерпретациям. В связи с этим возникает вопрос о том, создается ли в данном случае текст принципиально нового типа или вторичный медиатекст как результат когнитивной модификации первичной новостной информации.

Для того чтобы установить место рассматриваемого вида медиановостей в общей типологии текстов, необходимо обратиться к положениям теории вторичных текстов, изложенным в работах исследователей (см., например: [Вербицкая, 2000; Ионова, 2006; Полубитченко, 2017; и др.]).

В последние десятилетия лингвистика существенно расширила границы понятия «вторичности» текста. Основным критери- 
ем «вторичности» является принцип презентации реальной или воображаемой ситуации через отражение информационной структуры первичного текста [Агранович, 2006, c. 4]. Данное понимание существенно отличается от претерпевшего изменения в современных интерпретациях бахтинского представления о вторичности как о двояконаправленном слове (на предмет речи и на чужую речь), но не противоречит ему. В работах Л.М. Майдановой важнейшим критерием вторичности текста выступает замещение интенции текста-основы другой интенцией, что приводит к смене субъекта деятельности [Майданова, 1994]. М.В. Вербицкая, рассматривая вторичные тексты как специфическую форму «осмысления художественного опыта», особо выделяет их функцию «утверждения своих собственных эстетических позиций» и «идеологическую нагрузку», которую они несут, акцентируя внимание на стилистической вторичности [Вербицкая, 2000]. С.В. Ионова определяет вторичный текст как «интертекстуальное явление парадигматического типа, образующееся путем преобразования текстаосновы» [Ионова, 2006, с. 156], которым может послужить фактически любой текст, часть текста или совокупность текстов. Таким образом, специфика как порождения, так и интерпретации вторичного текста зависит от специфики порождения и интерпретации текста-прототипа, несмотря на то, что коммуникативная и функциональная направленность вторичного текста может существенно отличаться от соответствующей направленности первичного текста.

Механизм построения вторичных текстов достаточно подробно изучен на примере текстов различных жанров (см.: [Александрова, 2012; Вербицкая, 2000; Гаврикова, 2013; Ионова, 2006; и др.]), поскольку данный вопрос, несомненно, один из ключевых при установлении критериев первичности vs вторичности текста. Одной из первых работ, в которых подробно рассматривается вопрос порождения вторичного текста, является исследование А.И. Новикова и Н.Л. Сунцовой. В качестве механизма порождения первичного текста они выделяют авторский замысел, основой которого, в свою очередь, выступает взаимодействие интенции, мотива, коммуникативной задачи и темы-понятия. Соответствие текста замыслу автора определяет уникальность первичного текста [Новиков, Сунцова, 1999]. Вторичный же текст, как показано Н.М. Нестеровой, Ю.К. Поповой, отличает именно несамостоятельность замысла, или смысловая несамостоятельность [Нестерова, Попова, 2017, с. 58], что так или иначе отражено во всех вышеупомянутых концепциях. Например, С.В. Ионовой представлены две основные модели порождения вторичных текстов, первая из которых базируется на построении ментальной проекции текста-основы, постижении «его смысловой доминанты, вычленяемой путем компрессии единиц текста и в некоторой степени отрицания его формы» [Ионова, 2006, c. 173]. Данная модель порождения вторичного текста повторяет модель текстопорождения прототекста и включает в себя те же этапы концептуализации и репрезентации. Вторая модель опирается на механизмы субституции и трасформации, то есть вторичный текст разворачивается в результате трансформации поверхностной структуры текстаисточника. Таким образом, во второй модели промежуточным звеном выступает «не ментальная модель отражаемой в тексте ситуации, а модель самого текста» [Ионова, 2006, c. 174]. С данными моделями в некоторой степени соотносятся так называемые синтагматические и парадигматические оси интертекстуальности, описанные Ю.С. Гавриковой. Согласно данной концепции, синтагматическая ось интертекстуальности «формируется линейными связями произведений единого текстового пространства» [Гаврикова, 2013, с. 298]. Парадигматическая ось интертекстуальности связана с сознательной модификацией исходного авторского замысла и первичного текста, поэтому именно она, по мнению автора, имеет непосредственное отношение к созданию вторичных текстов.

Таким образом, существующие концепции вторичных текстов так или иначе основываются на критериях «вторичности», к которым относятся: 1) различные принципы порождения текста: первичный текст порождается самостоятельным авторским замыслом / авторской интенцией, вторичный текст харак- 
теризует «смысловая несамостоятельность», то есть его порождение - результат сложных ментальных трансформаций, детерминированных первичным текстом; 2) смена коммуникативной и функциональной направленности, поскольку вторичный текст выполняет иную коммуникативную задачу и реализует иную функцию в отличной от оригинальной коммуникативной ситуации. Здесь также уместно упомянуть типологию вторичных речевых произведений С.В. Ионовой, включающую четыре функциональных типа текстов: репродуктивные, интепретативные, адаптирующие, имитационные [Ионова, 2006].

В связи с рассмотрением понятия вторичности текста необходимо назвать критерии разграничения первичных и вторичных жанров применительно к политическому дискурсу. По мнению Е.И. Шейгал, «первичный дискурс образуют жанры институциональной коммуникации, составляющие основу собственно политической деятельности: речи, заявления, дебаты, переговоры, декреты, конституции, партийные программы, лозунги и т. д., а жанры бытового общения выступают по отношению к ним как вторичные. Вторичные жанры политического дискурса можно определить как “разговоры о политике”; они носят респонтивный характер и представляют собой комментирование, обсуждение, интерпретацию, одним словом, реакцию на действия» [Шейгал, 2000, с. 269]. Такая дифференциация первичных и вторичных жанров применима к массмедийному дискурсу, где медиановость относится к первичному, а ее комическое переосмысление и интерпретация к вторичному жанру.

Все вышеизложенное позволяет рассматривать изучаемый тип новостного текста как вторичный текст / жанр, который, вопервых, порождается при помощи смены авторской интенции (основная интенция первичного новостного текста - информировать; основная интенция вторичного текста - развлечь адресата), во-вторых, в процессе его порождения происходит смена коммуникативной и функциональной направленности (смена коммуникативной ситуации). Информационно-развлекательный текст, в классификации С.А. Ионовой, представляет собой интерпретативно-адаптирующий тип текста, потому что его цель состоит как в преобразовании текста в соответствии с авторской позицией, так и в его изменении в соответствии с новыми дискурсивными условиями его использования. Креативная интерпретация первичной новости с использованием средств комического ведет к ее переходу в иной жанр. Далее охарактеризуем механизм и специфику преобразования медиановости во вторичный текст / жанр.

В качестве эмпирического материала использовались тексты новостной рубрики, транслируемой в начале телевизионной передачи Первого канала «Вечерний Ургант» (выпуски 2017-2020 гг.). Всего проанализировано 530 наиболее популярных выпусков, критерием отбора стало количество просмотров выпусков передач, зафиксированных на видеохостинге YouTube.

\section{Результаты и обсуждение}

Поскольку в основе вторичной медиановости лежит развлекательная интенция, реализуемая с помощью различных средств комического, кратко охарактеризуем такие общепризнанные виды комического, как юмор, ирония, сатира и сарказм [Истомина, 2015; Палкевич, 2003; Попченко, 2005; и др.]).

Юмор традиционно трактуется как «мягкий» вид комического, отражающий положительное отношение к окружающей действительности и способный вызывать веселый смех или незлобивую улыбку.

Ирония представляет собой реализацию двуплановости, обнаруживающую расхождение между двумя образами реальности - позитивным, жизнеутверждающим и негативным, высмеивающим и осуждающим, и вербализацию двусмысленности, обусловленной наложением ироничного смысла на буквальный. Другими словами, ирония построена на принципе асимметрии, который проявляется в «количественном рассогласовании между двумя онтологическими формами иронии: на единицу плана выражения в ироническом высказывании или тексте приходится как минимум две единицы плана содержания» [Палкевич, 2003 , с. 193]. Объектом иронии, как правило, выступает авторитет (государственный орган или человек), заслуживающий разоблачения. 
Сатира, согласно М.М. Бахтину, определяется «как особое отношение творящего к изображаемой им действительности. Сатира есть образное отрицание современной действительности в различных ее моментах, необходимо включающее в себя - в той или иной форме и с той или иной степенью конкретности и ясности - и положительный момент утверждения лучшей действительности» [Бахтин, 1997, с. 35]. Объектом сатиры становятся социальные пороки, имеющие общественный резонанс, чаще всего соотносимые с нарушением норм морали и нравственности.

Высшей степенью обличения общественно опасных процессов характеризуется сарказм - язвительная, ядовитая насмешка, намеренно обнажающая пороки общества.

Возможно сопоставить перечисленные виды комического с точки зрения эмоциональной реализации: а) юмор характеризуется средней степенью эмоциональной насыщенности, средней интенсивностью выражения эмоций, низкой степенью агрессивности; б) ирония высокой степенью эмоциональной насыщенности (от добродушного подтрунивания до насмешки, высокомерия и превосходства, недовольства и раздражения из-за неудовлетворенности окружающим миром) и средней интенсивностью выражения эмоций; в) сатира средней степенью эмоциональной насыщенности (неудовлетворенность, сожаление), но высокой интенсивностью выражения осуждения и беспощадной критики; г) сарказм - крайней степенью эмоционального отношения и выражения, преобразующего высокий пафос отрицания в негодование, доходящего до границы с цинизмом. Ирония в отличие от других видов комического менее эксплицитна, но выделяется высокой интеллектуальностью на фоне других фрагментов комической картины мира.

Далее рассмотрим механизм трансформации информационной медиакартины мира в комическую и средства комического, создающие такое перевоплощение.

Заметим, что не весь новостной контент становится поводом для комического переосмысления. В производстве новостей одни события игнорируются, в то время как другие, наоборот, становятся новостным растиражированным продуктом. На селективный характер новостей при реализации задач социального конструирования влияет, по мнению А.Г. Пастухова, множество факторов, в том числе упрощение, идентификация и сенсация, формирование конформности по отношению к политическим или бизнес-элитам и т. д. [Пастухов, 2016]. Новости, которые в результате селекции стали доступными широкой аудитории, вновь подвергаются субъективному отбору. Вторичная селекция не зависит от социальной значимости события, его резонансности, а чаще всего обусловлена креативными интенциями журналиста.

Обращаясь непосредственно к практическому материалу, поясним, что «мишенями» вторичной новостной «заметки» становятся события разной степени значимости:

- новости из общественно-политической и экономической сфер:

(1) Минздрав поддержал запрет на курение около подъездов жилых домов (17.10.2017);

(2) В Госдуму хотят внедрить спецпредставителя по вопросам гендерного равенства и ввести соответствующий закон (23.10.2017);

(3) Россияне набрали рекордное количество кредитов, задолжав банкам почти 15 трлн. (01.03.2019);

- новости спорта, музыкальной, теле- и киноиндустрии:

(4) Disney снимет новую версию «Золушки», где главным героем станет темнокожий парень (26.10.2020);

(5) Впервые в истории Лиги чемпионов главным арбитром матча назначена женщина (01.12.2020);

- новости частной жизни известных личностей:

(6) Кейт Мидлтон и принц Уильям ждут ребенка (04.09.2017);

(7) Киркоров с размахом отметил день рождения дочери (04.12.2020);

- коммуникативное поведение, высказывания известной личности, всколыхнувшие Интернет:

(8) Шнуров назвал Басту понторезом и бабкой у подъезда (02.12.2020);

- лишенные какой-либо особой социальной значимости события / явления, курьезные 
случаи, в том числе видеоролики происшествий, выложенные в соцсетях:

(9) В Екатеринбурге дорожные службы положили новый асфальт (06.06.2017);

(10) Пес президента Франции на встрече главы государства с членами правительства справил нужду в камин (24.10.2017).

Благодаря средствам комического, приемам иносказания, гротеска, аллюзии и т. д. новость предстает в информационно трансформированном виде.

Обнаружено, что наиболее популярным средством комического, используемого для преобразования первичного новостного сообщения, выступает юмор, который обнаруживается в 78 \% всех проанализированных примеров. Приведем один из них:

(11) Минздрав поддержал запрет на курение около подъездов жилых домов на расстояние менее 10 метров от входа.

Как отмерить 10 метров от подъезда / чтоб покурить? Вышли из подъезда / идете / началась одышка / все / 10 метров... Курить уподъезда больше нельзя. Это спланированная акция для полного отказа от курения. Посмотрите / ты вышел из подъезда - тебе курить нельзя. Ты отошел на 10 метров- там медучреждение / там тоже нельзя курить / отошел - дальше школа / снова нельзя курить. Еще 10 метров автозаправка. Еще 10 метров / уже начинается дальневосточный гектар и его заселение. В статье ничего не сказано про запрет курения в подъездах. А значит / будем жить (17.10.2017).

Новость о социально полезных изменениях - о запрете курения возле жилых подъездов - подвергается юмористической трансформации благодаря: а) включению комического преувеличения (расстояние в десять метров достаточно быстро расширяется, достигая восточных пределов страны); б) приему смысловой инверсии (гиперболизированный негативный «исход» грядущего нововведения замещается оптимистичным выходом из затруднительного положения - возможность курения в подъезде).

Заметим, что в шутливо трансформированном виде предстают два типа новостных продуктов - новости разной степени актуальности без комического потенциала и новости, содержащие комический потенциал, как в следующем примере:
(12) В Твери пройдет фестиваль козлов и Козловых.

Второй международный фестиваль козла под девизом Козловы всех стран соединяйтесь пройдет в Твери 20 мая. Об этом сообщает издание Тверские ведомости. Состоится торжественная регистрация людей с козлиными фамилиями Козлов / Козлевич / Козловский. Участникам будут предложены развлечения / связанные с козлами - прыжки через гимнастического козла / забивание козла в домино / просмотр фильма Духлес / и другие развлечения / звонки бывшим / например (16.05.2017).

Комический потенциал новости позволяет ведущему использовать различные аллюзии на соотносимые с упомянутым животным виды развлечений, прецедентные феномены - известные фамилии и фразу Bce мужики - козль, скрывающуюся за шуткой о «бывших».

Интерес для анализа новостного «преображения» представляет ирония, используемая, как правило, реже (обнаружена в $18 \%$ рассмотренных примеров) и выступающая в социально-критической и дискредитирующей функциях. Например, новость:

(13) Временно исполняющий главы Дагестана Сергей Меликов на заседании по развитию градостроительства этого региона призвал предпринимателей отказаться от иностранных названий кафе и ресторанов (27.10.2020)-

реинтерпретируется ведущим при помощи нескольких иронических замечаний, прячущих за одобрением осуждение и насмешку, обнажающую нелепость происходящего:

(14) Понятно / что в Дагестане / как в любом другом регионе Российской Федерации / много насушных / наболевших / острых социальных проблем / вопросов. Приятно / что новый глава региона сразу занялся главной проблемой / это латинские названия кафе и ресторанов. Мы узнали благодаря этой фразе / откуда идет все зло... (27.10.2020).

Первичная новостная информация подвергается когнитивной переработке: собственно информационная составляющая редуцируется, смысловое содержание деформируется, появляются интерпретации, содержащие эмоционально-оценочные коннотации и критически осмысленные комментарии, информационный регистр переключается на интерпретативно- 
оценочный, что в итоге приводит к созданию комической / сатирической интерпретации действительности.

Необходимо отметить, что сарказм не входит в число основных приемов, используемых И. Ургантом, так как «жесткая» интерпретация новостного контента, очевидно, не является задачей ведущего. Однако ему также не удается воздержаться от этого приема. Данный вид комического используется для новостной интерпретации в $4 \%$ примеров.

Следующая новость построена на эффекте обманутого ожидания, когда за вполне безобидным введением следует контент, полностью меняющий его семантику:

(15) Есть ощущение / что Россия отходит от пандемии. Все чаще появляются признаки привычной / нормальной жизни / к которой мы привыкли и которую мы / честно говоря / ждем.

Депутаты устроили драку в Саратовской городской думе. Ох / да. Возвращаемся к привычной жизни. Их так и тянет друг другу. Устали от социального дистанцирования. (Цитируется новость) Встреча была посвящена неэтичному поведению двух членов областной думы. Первый нецензурно выражался на заседании рабочей группы Комитета по культуре. Второй оскорбил коллег на заседании Комитета по бюджету. Значит / на встрече по неэтичному поведению / драка. Видимо / на следующей встрече будет поножовщина. Может быть / саратовские депутаты думают / что встречи по неэтичному поведению / это встречи / где нужно как раз вести себя неэтично? С другой стороны / можно понять депутата же / хочется показать коллегам те удары / которые ты три месяца во время самоизоляции отрабатывал на жене (25.06.2020).

Контекстуальная ирония, основанная на противопоставлении понятий этичного поведения (лексема неэтичный четырежды повторяется в данном фрагменте, буквально притягивая к себе внимание зрителей) и физической агрессии, перерастает в сарказм: физическая агрессия представлена как естественный способ межличностного общения депутатов, их драки как олицетворение нормальной доковидной жизни, а наблюдение за драками депутатов как привычное и популярное развлечение граждан.

В создании комической интерпретации новостного события участвуют разноуровневые лингвостилистические средства и сред- ства непрямой коммуникации, в том числе аллюзии, риторические вопросы, метафоры, гиперболы, сравнения, намеки, колкости, издевки и т. д.

Например, в эфире от 05.02.2020 ведущий начинает программу с новости:

(16) Глава Роскосмоса Дмитрий Рогозин ответил на шутку Ивана Урганта о космонавтах.

В предыдущем эфире И. Ургант пошутил на тему снижения требований к кандидатам в отряд космонавтов, а именно что космонавтами смогут становиться люди с психическими отклонениями или судимостью. В ответ на это в твиттер-аккаунте робота Федора появился комментарий:

(17) Нет, Иван, речь идет лишь о снижении требований по зрению. Друзей своих не предлагайте. тарий:

Д. Рогозин выложил следующий коммен-

(18) Ну, а чего вы хотите? Восемь лет чуть ли не ежедневно вести развлекательную передачу, тут не только шутки и юмор закончатся, но и язык намозолится. Вот и приходится ржать то про религиозные чувства православных верующих, то про космонавтов-героев.

И. Ургант реагирует на твит робота Федора колкостью, адресованной Роскосмосу в целом:

(19) «...С робота что взять / понятно / бездушный кусок металла. Все функции свелись к одному / остроумно отвечать в Твиттере». Далее он продолжает, отвечая Д. Рогозину: «Зачем вспоминать конфликт / за который я уже извинился? При чем здесь верующие вообще? Зачем про это вспоминать? Мы это закрыли. Это все равно / если б я сейчас сказал / восемь лет для программы нашей / это много / а вот для строительства космодрома Восточный это вообще ничего / даже там ничего намозолиться не успело. Я ж так не говорю / я ж понимаю / что это к делу отношения не имеет» (05.02.2020).

Данная новостная ситуация соотносится с высказыванием одной известной личности (главы госкорпорации «Роскосмос») о коммуникативном поведении другой известной 
личности (ведущего популярной развлекательной программы). Сам факт появления такой новости служит развитию комического эффекта: во-первых, агрессивный выпад Друзей своux не предлагайте (прямая скрытая агрессия, согласно классификации А. Басса) представляет собой попытку публичного оскорбления, которое митигируется за счет как бы «неловкого» сокрытия его истинного адресанта. При этом автор оскорбительной фразы очевиден, что дает возможность И. Урганту сделать ответный шаг - прокомментировать ограниченные способности робота Федора и его бесполезность для космических исследований, задев таким образом разработчиков робота. Комический эффект достигается также за счет прецедентности: в памяти аудитории еще свежи шумиха и восторженные репортажи, связанные с созданием робота Федора, его доставкой на МКС и перспективностью его использования в космических исследованиях.

Свой ответ Д. Рогозину И. Ургант начинает с трех риторических вопросов зачем при чем - зачем, создавая тем самым легкую напряженность в аудитории. Далее наступает кульминационный пункт, построенный на антитезе восемь лет - это много - вообще ничего - ничего не успело. «Зеркальное» использование просторечного окказионализма намозолиться и сослагательного наклонения усиливают комический эффект.

Одним из часто используемых приемов является аллюзия. Приведем пример новости от 24.11.2020 о начале передачи власти избранному президенту США Джо Байдену:

(20) Дональд Трамп попросил / не приказал / а попросил / свою администрацию начать процесс передачи власти Джо Байдену. При этом действующий президент все еще не признал свое поражение на выборах. Он ответил / что готов продолжить судебные тяжбы. Мы продолжим борьбу / и я верю / что мы победим /- заявил американский президент / передавая бразды правления. Передача власти в Америке / это небыстрый процесс. Это в России / я устал / я ухожу / и все (24.11.2020).

В данном фрагменте содержится двойственный намек на авторитарный стиль управления. С одной стороны, авторитарный стиль в целом характерен для Д. Трампа, поэтому глагол попросил выглядит необыч- но в данном контексте. С другой стороны, последующая аллюзия на решение об отставке первого президента РФ Б.Н. Ельцина (Я устал, я ухожу) позволяет предположить, что автор намекает на авторитарный стиль правления в России в противоположность демократическому.

Помимо упомянутых средств комического, механизм новостной трансформации включает в себя комическое преувеличение и преуменьшение, приемы иносказания, комического несоответствия и комической неожиданности, разоблачения, а также отсылки к прецедентным феноменам. Нередко преобразование исходного новостного сообщения сопровождается карнавализацией и десакрализацией существующих норм и ценностей.

\section{Заключение}

Популярность у широкой аудитории медиановости в ее вторичном, трансформированном виде можно объяснить гедонизацией общественного сознания, информационной перегруженностью современного человека, с одной стороны, и низкой потребностью в аналитическом осмыслении информации - с другой.

Создание вторичного новостного текста / жанра осуществляется путем трансформации основного (первичного) новостного текста. Oсобенность вторичного медиапродукта - его принадлежность не столько к информационной, сколько к комической картине мира, моделирование которой становится возможным благодаря различным средствам комического, реализующим социально-критические, эстетические и развлекательные функции. Последняя позволяет снизить степень важности и серьезности первичного новостного сообщения.

В результате анализа механизма новостной трансформации установлено следующее: первичная новостная информация текста медиановости редуцируется, в то время как «наращивается» его прагматический компонент за счет использования средств комического, приемов гротеска, аллюзии, переакцентуации ценностей, лингвостилистических средств и др. В итоге конструируется вторичный новостной текст, характеризуемый рекомбинированным смысловым содержанием и субъективной интерпретацией первичной новости. 


\section{СПИСОК ЛИТЕРАТУРЫ}

Агранович Н. Б., 2006. Вторичные тексты в коммуникативно-когнитивном аспекте : автореф. дис. ... канд. филол. наук. М. 24 с.

Александрова А. А., 2012. Реализация категории аппроксимации в тексте пародии // Известия Российского государственного педагогического университета им. А.И. Герцена. № 153 (1). С. 38-45.

Бахтин М. М., 1997. Сатира // Собрание сочинений. В 7 т. Т. 5. М. : Рус. слов. С. 11-39.

Вартанова Е. Л., Смирнов С. С., 2009. СМИ России как индустрия развлечений // Медиаскоп. № 4. C. $13-16$.

Вербицкая М. В., 2000. Теория вторичных текстов (на материале современного английского языка) : монография. М. : МГУ. 220 с.

Гаврикова Ю. С., 2013. Соотношение парадигматической и синтагматической интертекстуальности в антиутопиях // Вестник Тихоокеанского государственного университета. № 4 (31). С. 297-306.

Евдокимов В. А., 2010. Инфотейнмент в массмедиа: панацея от скуки и эрзац дискуссии // Наука о человеке: гуманитарные исследования. № 5. С. 214-219.

Ерофеева И. В., 2014. Правда и истина в пространстве медиатекста: дихотомия справедливости // Гуманитарный вектор. № 4 (40). С. 84-91.

Ионова С. В., 2006. Аппроксимация содержания вторичных текстов. Волгоград: Изд-во ВолГУ. 380 с.

Истомина А. Е., 2015. Специфика реализации когнитивно-информационных категорий жанра «фельетон»// Грани познания. № 1 (35). C. $101-105$.

Майданова Л. М., 1994. Речевая интенция и типология вторичных текстов // Человек - Текст - Культура. Екатеринбург : Полиграфист. С. 81-104.

Мельникова Е. А., 2014. Точность и достоверность как критерии информативности текста новостного сообщения // Вестник Волгоградского государственного университета. Серия 2, Языкознание. № 5 (24). C. 94-100. DOI: http://dx.doi.org/ 10.15688/jvolsu2.2014.5.12.

Нестерова Н. М., Попова Ю. К., 2017. О проблеме дифференциации первичных и вторичных текстов // Вестник Пермского национального исследовательского политехнического университета. Проблемы языкознания и педагогики. №4. С. 52-61.

Новиков А. И., Сунцова Н. Л., 1999. Концептуальная модель порождения вторичного текста // Обработка текста и когнитивные технологии. № 3. C. 158-166. URL: http:// psycholinguistik.narod.ru/index/0-77 (дата обращения: 27.08.2020).
Палкевич О. Я., 2003. Человек ироничный: ирония как один из феноменов эгоцентрической направленности // Антропологическая лингвистика : Концепты. Категории : коллектив. моногр. к юбилею чл.-кор. РАН, д-ра филол. наук Нины Давидовны Арутюновой. М. ; Иркутск : Иркут. гос. лингв. ун-т. С. 168-194.

Пастухов А. Г., 2012. Инфотейнмент и эдутеймент: цифровые медиа против бумажных? // Филология и человек. № 4. С. 183-193.

Пастухов А. Г., 2016. Вопросы интердискурсивности и селекция новостей // Дискурс современных масс-медиа в перспективе теории, социальной практики и образования : сб. науч. работ. Белгород : ИД «Белгород». С. 57-68.

Полубитченко Л. В., 2017. Филологическая топология: теория и практика. М. : Флинта. 280 с.

Попченко И. В., 2005. Комическая картина мира как фрагмент эмоциональной картины мира // Язык. Человек. Общество : сб. науч. тр. Владимир : Владим. гос. пед. ун-т. С. 86-94.

Распопова С. С., 2012. О понятии «жанр» в теории журналистики // Вестник Челябинского государственного университета. № 6 (260), вып. 64 . С. 114-117.

Шейгал Е. И., 2000. Семиотика политического дискурса : монография. М. ; Волгоград : Перемена. $367 \mathrm{c}$.

\section{REFERENCES}

Agranovich N.B., 2006. Vtorichnye teksty $v$ kommunikativno-kognitivnom aspekte: avtoref. dis. ... kand. filol. nauk [Secondary texts in the communicative and cognitive aspect. Cand. philol. sci. abs. diss.]. Moscow. 24 p.

Aleksandrova A.A., 2012. Realizatsiya kategorii approksimacii $\mathrm{v}$ tekste parodii [Realization of the category of approximation in parody texts]. Izvestiya Rossiyskogo gosudarstvennogo pedagogicheskogo universiteta im. A.I. Gercena [Izvestia: Herzen University Journal of humanities \& sciences], no. 153 (1), pp. 38-45.

Bahtin M.M., 1997. Satira. Sobranie sochineniy. $7 t$. T. 5 [Collected Works. In 7 Vols. Vol. 5]. Moscow, Russkie slovari Publ., pp. 11-39.

Vartanova E.L., Smirnov S.S., 2009. SMI Rossii kak industriya razvlecheniy [Russian media as an entertainment industry]. Mediaskop, no. 4, pp. 13-16.

Verbickaya M.V., 2000. Teoriya vtorichnykh tekstov (na materiale sovremennogo angliyskogo yazyka) [Theory of secondary texts (based on the material of modern English)]. Moscow, MGU. $220 \mathrm{p}$. 
Gavrikova Yu.S., 2013. Sootnoshenie paradigmaticheskoy i sintagmaticheskoy intertekstualnosti v antiutopiyah [Co-Relation of paradigmatic and syntagmatic intertextuality in distopian literature]. Vestnik Tihookeanskogo gosudarstvennogo universiteta, no. 4 (31), pp. 297-306.

Evdokimov V.A., 2010. Infoteynment v mass-media: panatseya ot skuki i erzats diskussii [Infotainment in mass media: a panacea for boredom and ersatz discussions]. Nauka o cheloveke: gumanitarnye issledovaniya, no. 5, pp. 214-219.

Erofeeva I.V., 2014. Pravda i istina v prostranstve mediateksta: dikhotomiya spravedlivosti [Subjective truth and objective truth in space of mediatext: the dichotomy of justice]. Gumanitarnyy vector [Humanitarian vector], no. 4 (40), pp. 84-91.

Ionova S.V., 2006. Approksimatsiya soderzhaniya vtorichnykh tekstov [Approximation of the secondary texts' content]. Volgograd, Izd-vo VolGU. 380 p.

Istomina A.E., 2015. Spetsifika realizatsii kognitivnoinformacionnykh kategoriy zhanra «feleton» [Realization of cognitive-informative categories of the "feuilleton" genre]. Grani poznaniya, no. 1 (35), pp. 101-105.

Maydanova L.M., 1994. Rechevaya intentsiya i tipologiya vtorichnykh tekstov [Speech intention and typology of secondary texts]. Chelovek Tekst - Kultura [Man - Text - Culture]. Yekaterinburg, Poligrafist Publ., pp. 81-104.

Melnikova E.A., 2014. Tochnost i dostovernost kak kriterii informativnosti teksta novostnogo soobshcheniya [Accuracy and reliability as criteria of informativeness in the news story]. Vestnik Volgogradskogo gosudarstvennogo universiteta. Seriya 2. Yazykoznanie [Science Journal of Volgograd State University. Linguistics], no. 5 (24), pp. 94-100. DOI: http:// dx.doi.org/10.15688/jvolsu2.2014.5.12.

Nesterova N.M., Popova Yu.K., 2017. O probleme differentsiatsii pervichnykh i vtorichnykh tekstov [The problem of differentiating primary and secondary texts]. Vestnik Permskogo natsionalnogo issledovatelskogo politehnicheskogo universiteta. Problemy yazykoznaniya i pedagogiki, no. 4, pp. 52-61.
Novikov A.I., Suncova N.L., 1999. Kontseptualnaya model porozhdeniya vtorichnogo teksta [A conceptual model of the secondary text's generation]. Obrabotka teksta $i$ kognitivnye tekhnologii [Text processing and cognitive technologies], no. 3, pp. 158-166. URL: http:// psycholinguistik.narod.ru/index/0-77 (accessed 27 August 2020).

Palkevich O.Ya., 2003. Chelovek ironichnyy: ironiya kak odin iz fenomenov egotsentricheskoy napravlennosti [Ironic man: irony as one of the phenomena of egocentric orientation]. Antropologicheskaya lingvistika: Kontsepty. Kategorii [Anthropological Linguistics: Concepts. Categories]. Moscow, Irkutsk, Irkutskiy gosudarstvennyy lingvisticheskiy universitet, pp. 168-194.

Pastukhov A.G., 2012. Infoteynment i eduteyment: cifrovye media protiv bumazhnykh? [Infotainment and edutainment: digital media versus paper media?]. Filologiya i chelovek, no. 4, pp. 183-193.

Pastukhov A.G., 2016. Voprosy interdiskursivnosti i selektsiya novostey [Issues of interdiscursivity and news selection]. Diskurs sovremennyh massmedia $v$ perspektive teorii, socialnoy praktiki $i$ obrazovaniya [Discourse of modern mass media in the perspective of theory, social practice and education]. Belgorod, ID «Belgorod», pp. 57-68.

Polubitchenko L.V., 2017. Filologicheskaya topologiya: teoriya i praktika [Philological topology: theory and practice]. Moscow, Flinta Publ. 280 p.

Popchenko I.V., 2005. Komicheskaya kartina mira kak fragment emocionalnoy kartiny mira [The comic picture of the world as a fragment of the emotional picture of the world]. Yazyk. Chelovek. Obshchestvo [Language. Person. Society]. Vladimir, Vladimirskiy gosudarstvennyy pedagogicheskiy universitet, pp. 86-94.

Raspopova S.S., 2012. O ponyatii «zhanr»v teorii zhurnalistiki [On the concept of "genre" in the theory of journalism]. Vestnik Chelyabinskogo gosudarstvennogo universiteta [Bulletin of Chelyabisk State University], no. 6 (260), iss. 64, pp. 114-117.

Sheygal E.I., 2000. Semiotika politicheskogo diskursa [Semiotics of political discourse]. Moscow, Volgograd, Peremena Publ. 367 p. 


\section{НОВЫЕ АСПЕКТЫ ИЗУЧЕНИЯ ЖАНРОВ И ТИПОВ ТЕКСТОВ}

\section{Information About the Authors}

Yana A. Volkova, Doctor of Sciences (Philology), Professor, Department of Foreign Languages in Theory and Practice, Peoples' Friendship University of Russia, Miklukho-Maklaya St, 7, 117198 Moscow, Russia, yana.a.volkova@gmail.com, https://orcid.org/0000-0003-1456-5881

Nadezhda N. Panchenko, Doctor of Sciences (Philology), Professor, Head of the Department of Linguistics, Volgograd State Socio-Pedagogical University, Prosp. Lenina, 27, 400066 Volgograd, Russia, panchnn@yandex.ru, https://orcid.org/0000-0003-4498-5262

\section{Информация об авторах}

Яна Александровна Волкова, доктор филологических наук, профессор кафедры теории и практики иностранных языков, Российский университет дружбы народов, ул. Миклухо-Маклая, 7 117198 г. Москва, Россия, yana.a.volkova@gmail.com, https://orcid.org/0000-0003-1456-5881

Надежда Николаевна Панченко, доктор филологических наук, профессор, заведующая кафедрой языкознания, Волгоградский государственный социально-педагогический университет, просп. Ленина, 27, 400066 г. Волгоград, Россия, panchnn@yandex.ru, https://orcid.org/0000-0003-4498-5262 